\title{
Mitigating the COVID-19 spread: a challenge and an opportunity
}

\section{Mitigar la propagación de la COVID-19: un desafío y una oportunidad}

\author{
Howard Ramírez-Malule ${ }^{1 \S}$, Diego Ramirez-Malule², David Gómez-Ríos ${ }^{3}$ \\ ${ }^{1}$ Universidad del Valle, Facultad de Ingeniería, Escuela de Ingeniería Química, Cali, Colombia \\ ${ }^{2}$ Universidad de Antioquia, Facultad de Ingeniería, Departamento de Ingeniería Industrial, Medellín, \\ Colombia \\ ${ }^{3}$ Universidad de Antioquia, Departamento de Ingeniería Química, Grupo de Investigación en \\ Simulación, Diseño, Control y Optimización de Procesos (SIDCOP), Medellín, Colombia \\ §howard.ramirez@correounivalle.edu.co,diegof.ramirez@udea.edu.co,dandres.gomez@udea.edu.co
}

Recibido: 21 de abril de 2020 - Aceptado: 05 de mayo de 2020

\section{Dear Editor,}

The respiratory disease COVID-19 caused by the novel coronavirus SARS-CoV-2 and initially located in China, arrived to Colombia via the international flights between Colombia, Europe and the US, since those destinations are among the most frequented by the Colombian citizens (1). Concerns about the internal and external migratory flows were raised by medical and scientific institutions due to the ease of contagion and the absence of validated therapeutic alternatives. In fact, treatment for COVID-19 has been limited to symptomatology management and standard therapeutics for viral pneumonia, although research on antivirals has been advancing rapidly ${ }^{(2)}$.

In view of the emergency, the Colombian government declared the quarantine for all the population since $25^{\text {th }}$ March, 2020 as a measure to mitigate the expansion of COVID-19 in the country. This has been followed by a staggered transition for economic recovery. The mobility 
restrictions showed early some opposite consequences to their purpose. As observed in other countries, the measures caused a mass purchase of products, formation of crowds in grocery, department stores and local markets. The fear of shortage also caused exhaustion of products, long journeys and accumulation of large numbers of people in stores, bank offices and ATMs. At less $74 \%$ of the Colombian population is usually concentrated in urban areas like Bogotá, Medellin, Cali, Barranquilla and Cartagena; as expected, most of the COVID-19 initial cases $(96 \%)$ were located in those cities ${ }^{(3)}$. The declaration of the restrictions motivated to a considerable number of inhabitants of the large cities to move back to their hometowns crowding the bus stations, airports and even causing traffic jams. Unfortunately, the restriction measures unleashed an inadequate behavior of some citizens, increasing the risk of infection.

Currently, the contagions due to SARS-CoV-2 are present in 37 departments and districts and the fears of carrying the disease to rural areas and poor departments came true ${ }^{(3)}$. Some people anticipated the quarantine and traveled, even to small towns and remote regions. While large cities are more prepared and have more resources to face the increasing rate of cases, inhabitants of remote areas like Chocó, La Guajira Vaupes and Amazonas, and in general small and distanced towns in all departments are in particular vulnerability as consequence of poverty, violence, deficient institutional coverage, malnutrition, little access to health care, education, and decent housing ${ }^{(4)}$. In the view of an imminent and gradual reopening of national economy, the inhabitants of those areas have less opportunities of getting adequate treatment and the spread of COVID-19 in those remote regions could become a major scenario of emergency if strict prevention measures are not applied.
During the rest of the year the discussion of the revival of the economy and industry will occupy the national agenda. The International Monetary Fund (IMF) projects a real GDP growth for Colombia of $-2.4 \%$ and an increase of consumer prices of $3.5 \%$ due to the restriction measures and economic stoppage ${ }^{(5)}$. Moreover, before the quarantine declaration, the industrial production was slowly growing $(4.6 \%)$ while unemployment was also increasing $(12.2 \%)^{(6,7)}$. However, under the current situation the real effects of COVID-19 on industry and employment remain to be seen.

A global decrease in demand is expected, especially in the commodities sector. The accumulated decline of world chemical industry production as consequence of COVID-19 emergency is $3.2 \%$, which adds to the known depression of oil industry ${ }^{(8)}$. Despite this unoptimistic scenario, all size industries connected to prevention activities and products might find interesting opportunities. We refer specifically to medicines, pharmaceuticals, biosafety, personal care, protective equipment, cleaning and disinfection products and services, so does the associated logistics and supply chains. As representative examples, the sales growth of over-the-counter-drugs, supplements and vitamins due to the COVID-19 effect were $82,43,33 \%$, respectively ${ }^{(8)}$. Similarly, the personal care, hygiene and household cleaning product sales grew $31.6 \%{ }^{(8)}$. Those products and services must arrive also to the most vulnerable areas of the country in enough quantities and fair prices to avoid shortages and speculation. We are facing a national new reality and the daily economy will be permeated with hygiene protocols, cleaning procedures, controlled occupancy and prevention measures. This is a challenge and also an opportunity.

We agree the restrictions taken for limiting the spreading of the disease. It is also clear that the economy must be reopened to limit the negative 
impact on people. Moreover, all people must adjust to this new reality. In contrast with the measures applied during the early stages of the pandemic, the reopening measures must be carefully planned and coordinated. It is crucial to implement adequate communication and explanation channels; prevention measures must reach all the corners of the country as well. The less-expensive way to deal with this pandemic is prevention and, as here presented, this prevention can also contribute to mitigate the decline of some of the non-resistant sectors of the economy, even favoring the ventures and jobs creation.

\section{Conflict of interest statement}

None.

\section{Funding sources}

None.

\section{References}

(1) Gómez-Ríos D, Ramirez-Malule D, Ramirez-Malule $H$. The effect of uncontrolled travelers and social distancing on the spread of novel coronavirus disease (COVID-19) in Colombia. Travel Med Infect Dis. 2020:101699.

Doi:

10.1016/j.tmaid.2020.101699.

(2) Gómez-Ríos D, López-Agudelo VA, Ramírez-Malule H. Repurposing antivirals as potential treatments for SARS-CoV-2: From SARS to COVID19. J Appl Pharm Sci. 2020;10(5):1-9. Doi: 10.7324/JAPS.2020.10501.

(3) Instituto Nacional de Salud de Colombia. COVID 2019 en Colombia [Internet]. 2020 [Consulted 2020 May 24]. Available from: https://www.ins.gov.co/Noticias/Paginas/ Coronavirus.aspx
(4) Pan American Health Organization. Health in the Americas [Internet]. Washington, D.C.; 2017. Available from: https://www.paho.org/salud-en-lasamericas-2017/?p=2342.

(5) International Monetary Fund (IMF). Colombia [Internet]. 2020 [Consulted 2020 Apr 21]. Available from: https://www.imf.org/en/Countries/COL.

(6) Departamento Administrativo Nacional de Estadística (DANE). Empleo y desempleo [Internet]. 2020 [Consulted 2020 Apr 21]. Available from: https://www.dane.gov.co/index.php/estad isticas-por-tema/mercado-laboral/empleoy-desempleo.

(7) Departamento Administrativo Nacional de Estadística (DANE). Encuesta mensual manufacturera con enfoque territorial [Internet]. 2020 [Consulted 2020 Apr 21]. Available from: https://www.dane.gov.co/index.php/estad isticas-por-tema/industria/encuestamensual-manufacturera-con-enfoqueterritorial-emmet.

(8) Statista. Colombia COVID-19 statistics [Internet]. 2020 [Consulted 2020 Apr 21]. Available from: https://www.statista.com/statistics/11044 67/pharmaceutical-products-salesgrowth-category-colombia-coronavirus/. 

(c) $\$\left(\begin{array}{l}\text { Este trabajo está licenciado bajo una Licencia Internacional Creative Commons Reconocimiento- } \\ \text { NoComercial-CompartirIgual 4.0 }\end{array}\right.$ 